\title{
APROXIMACIÓN A LA TECNOLOGÍA COMO CONTROL Y GUERRA DESDE LA FILOSOFÍA DE LA CULTURA
}

\begin{abstract}
AN APPROACH TO TECHNOLOGY AS CONTROL AND WAR FROM THE PERSPECTIVE OF PHILOSOPHY OF CULTURE
\end{abstract}

Enrique Anrubia Aparici ${ }^{a^{*}}$

Fecha de recepción y aceptación: 12 de febrero de 2021 y 11 de junio de 2021

DOI: https://doi.org/10.46583/scio_2021.20.807

Resumen: Siguiendo las ideas clásicas, la tecnología se entiende como una especie de control del movimiento. Este control específico se mostrará históricamente en el campo militar. Sabiendo que nuestra era se autocomprende como un período tecnológico, este artículo intenta explicar cuáles son las particularidades de esta tecnología militar relacionadas con los tiempos modernos. Con ese propósito, y junto a un breve resumen de las tecnologías militares, el objetivo será reconocer una nueva forma de control de la realidad de acuerdo al nuevo lugar de las tecnologías.

Palabras clave: guerra, filosofía de la cultura, antropología de la violencia, tecnología. Herrera.

${ }^{a}$ Dpto. de Humanidades. Facultad de Humanidades y Comunicación. Universidad CEU Cardenal

${ }^{*}$ Correspondencia: Universidad CEU Cardenal Herrera. Facultad de Humanidades y Educación. Calle Luis Vives, 1. 46115 Alfara del Patriarca (Valencia), España.

E-mail: enriqueanrubia@uchceu.es 
Abstract: Following classic ideas, technology is understood as a kind of control of movement. This specific control will be historically shown at the military field. Knowing that our Era is self-understood as a technological period, this paper tries to explain which are the specifics features of this military technology related to the modern times. According to this purpose, together with brief History of military technologies, the main goal will be to recognize a new and unprecedented way of control of the reality according to new place of technologies.

Keywords: war, philosophy of culture, anthropology of violence, technology.

\section{$\S 1$. SOBRE LA TECNOLOGÍA COMO CONTROL}

\subsection{La tecnología como posibilidad del mundo}

Casi todos los paleoantropólogos están de acuerdo en que una de las causas formales extrínsecas que canalizó las posibilidades de habitabilidad de espacios del sapiens fue el control del fuego ${ }^{1}$. "La geografía del fuego y la geografía de los humanos es así coextensiva. Si se rastrea la historia del fuego se está rastreando la historia humana. A ese respecto, dar constancia de los fuegos humanos cuenta las historias que han configurado su historia, que explican quiénes son" (Pine, 1997: 13). Aunque se tiene constancia de su uso desde el neandertal ${ }^{2}$, parece que su infrecuente utilización (en términos de cotidianidad y estilo de vida) y la irregularidad de su descubrimiento en los

${ }^{1}$ Sobre el control del fuego, cfr. R. Bellomo (1993). A methodological approach for identifying archaeological evidence of fire resulting from human activities. Journal of Archaeological Science 20, 525-554.

${ }^{2}$ En el caso del Neandertal, Rosas afirma que "se han encontrado evidencias directas o indirectas del uso del fuego para la conservación de la comida, el ahumado de la carne y pescado y el asado de frutos y productos vegetales [...]. En su conjunto, se puede afirmar que los neandertales hacían un uso extensivo y relativamente del fuego y ejercían sobre él un control preciso" (Rosas, 2010: 89). Aunque pueda aparentar contradictorio, Rosas no está afirmando que el dominio del fuego comparezca en ellos, sino el control de su uso. Será el sapiens el que logre la domesticación y maestría sobre este. 
yacimientos (en términos de dataciones y frecuencia de su hallazgo) convierten al sapiens en el verdadero maestro del fuego ${ }^{3}$.

No es anecdótico que en la expresión académica "uso del fuego" en el ser humano se contenga la adscripción de su control, es decir, su producción deliberada, porteo y mantenimiento más allá de sus causas naturales. De hecho, las condiciones en las que el neandertal daba cauce al fuego eran, para nuestra sorpresa, climatológicamente desfavorables: poseía el fuego en épocas cálidas, pero no así en invierno, y pasaba largos períodos sin él. Algunas hipótesis sugieren que esa circunstancia pudiera deberse a que las tormentas eléctricas -que son la causa natural más regular del fuego- se dan claramente en períodos estivales". Y es que "manipular el fuego exige atención y por fuerza influyó en la transformación cerebral. Su manipulación igualmente debió de repercutir en un mayor esfuerzo comunicativo y, por tanto, el lenguaje. Su mantenimiento debió inducir una mayor complejidad social, al exigir actos anticiclos para vigilarlo durante la noche ante los predadores, de lo que dependía la supervivencia del grupo" (Turbón, 2006: 214).

Sea como fuere, parece que el mito platónico de Prometeo (Protágoras 320c-323a) no era ni tan presuntuoso ni tan vano al otorgar con el fuego al ser humano la posibilidad, aunque aún embrionaria, de su humanidad. La comparecencia del fuego no es circunstancial porque "todos los animales sin excepción [salvo el ser humano] huyen del fuego" (Turbón, 2006: 2135). La morfoanatomía del sapiens, como deja traslucir Platón, es metafórica pero certeramente pírica. Un fuego que bien resulta tanto la posibilidad de su vivir como el modo natural de dar operatividad a su biología, es decir, entender la cultura como una continuatio natura. Por eso, advirtió Geertz, "somos

\footnotetext{
${ }^{3}$ Véase W. Roebroeks y P. Villa (2011). On the earliest evidence for habitual use of fire in Europe. Proceedings of the National Academy of Science of the United States of America 108, 5209-14. También: Dennis M. Sandgathe, Harold L. Dibble, Paul Goldberg, Shannon P. McPherron, Alain Turq, Laura Niven y Jamie Hodgkins (2011). Timing of the appearance of habitual fire use. Proceedings of the National Academy of Science of the United States of America 108, 29 y sig.

${ }^{4}$ Cfr. P. Goldberg et al. (2010). New evidence on Neandertal use of fire: Examples from Roc de Marsal and Pech de l'Azé IV. Quaternary International (207).

${ }^{5}$ Existen evidencias de que los chimpancés son capaces de prestar cierta atención al fuego, con un mínimo de comprensión sensible sobre este. Pero más allá de eso, solo homo es capaz de su comprensión y practicidad. En ese sentido, puede verse una versión opuesta a la aquí propuesta en Ruetz y LaDuke (2010).
} 
animales incompletos o inconclusos, dice Geertz, que nos completamos o terminamos por obra de la cultura" (Geertz, 2000: 55).

Ningún animal diurno ha decidido en su historia "vivir la noche", pero vivir la noche es generar luz en la oscuridad y crear "la independencia de la luz solar" (Turbón, 2006: 213). Quizás, desde que el sapiens encontró y controló el fuego empezó la noche a ser algo nuevo para la propia noche, y, desde luego, empezó a ser más habitable. Pero si la noche dejó de ser solo noche para dar cabida en ella a una variante inesperada de la vida diurna, cabe decir que también el fuego dejó de ser "solo fuego". Dar un uso a algo es sobre todo y primeramente eso: dar, legar al mundo algo que el mundo desde sí mismo no daba de sí. "La domesticación del fuego, escribe Marín, supuso la ampliación de la habitabilidad al conjunto del planeta. Pero esa globalización espacial es correlativa a la completa habitabilidad del tiempo que implicó la victoria sobre la noche y el invierno, en cuyo seno ya era posible abrir la luz y el calor del día" (Marín, 2019: 68). Así que, en cierto modo, la técnica y el pensar sobre la realidad van de la mano, porque dicho en términos opuestos, no se puede hacer luz a la luz del día.

Dar luz a la oscuridad, casi como una donación divina, es tener cierta idea de lo que antes no existía pero podría existir. No se trata de que no se puede "hacer" algo si no se "sabe hacer", sino de que no se puede hacer nada si uno no sabe lo que el mundo ofrece como mera posibilidad. Así que en toda técnica hay cierta metafísica, $y$, en cierto modo, este mundo es un mundo de posibilidades que convierte la técnica, decía Ortega, en la propia posibilidad de "crearnos posibilidades completamente nuevas produciendo objetos que no hay en la naturaleza del hombre" (Ortega, 1983: 333).

Con esa misma sintonía, decía Heidegger que la técnica es sacar (desvelar) posibilidades al mundo que el mundo por sí mismo no ofrece : "¿Qué tiene que ver la técnica con el desocultar? Respuesta: Todo. Pues, en el desocultar

\footnotetext{
${ }^{6}$ Véase especialmente M. Heidegger (1977). Der Ursprung des Kunstwerkes. En V. Klostermann, Holzwege, GA 5. Frankfurt a. M., 1-75. Traducción castellana en M. Heidegger (1960). Sendas Perdidas, Buenos Aires: Editorial Losada, $2^{\mathrm{a}}$ ed.; también en M. Heidegger (1995). Caminos del Bosque. Madrid: Alianza Editorial.
} 
se funda todo producir" (Heidegger, 1958: 60)7, llega a decir Heidegger, haciendo de la técnica uno de los lugares -aunque no siempre- del "pres-ente" de la verdad (Heidegger, 1958: 61). La técnica desvela el mundo como oportunidad para el propio mundo, pues "es un error pensar que el hombre inventa la flecha porque tiene necesidad de comer [pájaros]. El hombre inventa la flecha porque descubre la oportunidad en la rama" (Polo, 1991: 68).

Sin embargo, la idea heideggeriana es al mismo tiempo una crítica y una cautela a la modernidad entendida como proyecto en el que la ciencia se expone en su última finalidad como saber técnico e instrumental. Si bien Bacon y Galileo son considerados como los padres de esa transformación del saber como saber instrumental y del mundo como su banco de pruebas, parece que son Leibniz y Newton (y sus mutuas discusiones) los que le dan justificación metafísica con el concepto (aún filosófico pero no tamizado en la sociedad del siglo XVII) de "progreso": "se puede incrementar la dominación técnica del mundo porque cabe un interpretación dinámico-mecánica del mundo" (Polo, 1991: 27). Ahora bien, si este mundo se define leibnicianamente como "el mejor de los mundos posibles", entonces el mundo ya no puede ofrecer posibilidad alguna y la técnica solo adquiere sentido en su propia producción ${ }^{8}$, esto es, su producción es su propia justificación, un hacer por hacer. Aquel "saber es poder" de Bacon se transforma en un "hacer porque se puede hacer" y no porque se sabe. Es ahí donde Heidegger, y también Ortega, advierten el límite de la justificación filosófica del saber como saber técnico, es decir, los límites de la poiesis aristotélica en tanto que techné.

Tampoco cabe decir que habría técnica, parafraseando a Leibniz, si este mundo solo fuera "un mundo posible", aunque no el mejor, porque si todo fuera posibilidad y solo fuera lo posible, entonces cabría advertir y denunciar que "el peor de los mundos reales" es mejor mundo que todos los mundos posibles juntos.

${ }^{7}$ Die Frage nach der Technik. En Vorträge and Aufsätze, Neske, Pfullingen, 1967 (I), 5-36. He utilizado la traducción castellana en M. Heidegger (1958). La pregunta por la técnica, trad. F. Soler en Revista de Filosofia 1, Santiago de Chile. También en Ciencia y Técnica. Santiago de Chile: Editorial Universitaria, 1984.

8 "El hecho de que el hombre se convierta en sujeto y el mundo en objeto, es una consecuencia de la esencia de la técnica que se establece a sí misma y no al contrario”. M. Heidegger (1996). ¿Y para qué poetas? Caminos de bosque. Madrid: Alianza Editorial, 215 (el subrayado es mío). 
Pero no parece que ese haya sido el caso en ninguno de los casos, porque desde el siglo Xx, y posiblemente desde el XIX, el mundo se ha transformado de un modo nunca antes visto. Así que puede haber una crítica a la técnica o una alabanza a esta, tal y como parece que hizo Heidegger en ambos ca$\operatorname{sos}^{9}$, pero de cualquiera de las maneras el mundo es el campo de dominio y crecimiento del ser humano y del propio mundo, o dicho con Heidegger, el mundo también es zuhandenheit (lo "a la mano"). El mundo como paraíso solo se hace jardín en el mandato veterotestamentario de dominar la tierra. Pero tanto si el dominio del mundo se interpreta como poder o imperar (imperium), o bien como casa y habitalidad (domus), en cualquiera de los casos, el ser humano está en el mundo como pez en el agua y no como pez en la pecera.

\subsection{La tecnología como control del movimiento}

Posiblemente el autor clásico más recurrente para hablar de la técnica no sea Heidegger, ni Bacon u Ortega -y la lista sería infinita-, sino Aristóteles. El mundo no se amplía en la mentalidad fixista de un griego, no al menos en el sentido en que los modernos entendemos la técnica, el mundo y la relación entre ambos. $\mathrm{O}$ dicho en términos cronológicos: es anacrónico asociar al concepto de "técnica" de Aristóteles a una visión moderna. Sea lo que sea la técnica en sentido aristotélico, no es vista como "posibilidad del mundo", si entendemos "mundo" como el lugar de la metafísica contemporánea y su consiguiente permuta por la antropología, tal y como hace Heidegger.

Para comprender, al menos parcialmente, el concepto aristotélico de técnica, o en su expresión latina "arte" (ars), resulta reveladora la interpretación de Blumenberg de esta. Si algunos filósofos modernos, y muchos de los más contemporáneos, han entendido la técnica como expresión fundamental de una metafísica (de comprensión de la realidad en su totalidad), no es solo porque la técnica adquirió una posición nueva, sino porque la

\footnotetext{
${ }^{9}$ Ejemplo de crítica en Heidegger: "Se muestra ahora que la techné es un modo inauténtico del desvelamiento” (M. Heidegger, Sophistes, GA 19, 41).
} 
metafísica clásica postergó la suya. Abandonar un sentido específico de qué se entiende por "ente" o "realidad" permite no tanto y no solo elaborar un nuevo sentido de metafísica, sino redefinir conceptos como "lo técnico" que la van incluir. Así que, advierta el lector, aquí se expondrá sumariamente a Aristóteles -y parte de Platón- como ejemplo clarificador de esa distinción (en la que el estagirita es solo un "contraste" necesario) y como precursor de una nueva acepción que se usará posteriormente.

El caso de Aristóteles es revelador porque permite, por un lado, adquirir al lector la visión de cómo la técnica se vuelve autónoma (es irrelevante al mundo si "mundo" es lo que la metafísica muestra y por extensión a su cosmovisión) y ofrece, por otro, su comprensión en función del movimiento. Netamente: la contemporaneidad hará del mundo "producción" y una física sin metafísica, es decir, puro tiempo y movimiento incausados.

Aristóteles asoció la técnica o arte como un hacer de lo práctico, pero en ningún caso entiende o sugiere que la técnica amplíe el mundo, si por mundo se entiende lo natural (phýsis). Si la técnica es en sentido moderno ampliación de la operatividad de la realidad, y la phýsis (naturaleza), según Aristóteles, es principio de operaciones, la única posible ampliación del mundo en Aristóteles es circular, es decir, es "un progreso de hacía sí mismo y hacia el acto (entelécheia)" (Aristóteles, Acerca del alma II, 5: 417 b 6-7). Así, si como escribe Spaemann, "la naturaleza según Aristóteles [es] aquello que tiene en sí mismo el principio de movimiento y el reposo" (Spaemann, 1989: 30), el movimiento no puede ser visto como la ampliación o transformación final de su esencia, sino como su despliegue circular.

Lo que puede ser entendido como cultural o técnico en sentido moderno, Aristóteles solo puede verlo como dilatación natural de las cosas naturales por naturaleza (phýsei). Por eso, la polis o lo político, que en una mentalidad moderna sería algo cultural e incluso tecnocrático, para Aristóteles es de suyo una de las formas naturales de lo humano, esto es, "resulta, pues, manifiesto que la ciudad es una de las cosas naturales, y que el hombre es por naturaleza un animal social (zoon politikón), y que el insocial por naturaleza y no por 
azar o es mal hombre o más que hombre, como aquel quien Homero increpa: sin tribu, sin ley, sin hogar" (Política 1253 a 7-13) ${ }^{10}$.

Explica Blumenberg que, tanto en Platón como en Aristóteles, la verdad de la técnica está de algún modo prestada por lo que posee de verdad la naturaleza (Blumenberg, 1951: 463), de tal manera que la técnica no puede ser entendida ni producir propiamente más que lo que ya hay (al menos "en potencia" en Aristóteles o como "participación” en Platón). Tal es en parte la razón de que ambos autores consideren la mímesis como concepto basal de la técnica, porque es como mucho el ejercicio de copia de la ejemplaridad de la realidad aún sus productos más artísticos y menos productivos (mímesis práxeos en la Poética de Aristóteles).

En el libro X de la República, Platón rechaza a los artistas porque imitan la naturaleza, pero atribuye al demiurgo una función imitativa y productora en cuanto que es capaz de sacar y reproducir la ejemplaridad de las propias ideas: si las Ideas -que Blumenberg las interpreta como "orientaciones ejemplares" (Blumenberg, 1947: 36)- son canónicas (en el sentido más profundo de cánon: medida), el demiurgo no solo sabe cómo es lo que ha de imitar, sino cómo ha de imitarlo. Pero, entonces, "la plenitud de la correspondencia entre Ideas y fenómenos viene a ser la unidad y plenitud del cosmos en relación con el concepto de posibilidad" (Blumenberg, 1981: 71), es decir, "en la obra del hombre realmente no pasa nada. El producto del hombre no tiene ninguna verdad en sí" (Blumenberg, 1981: 70), sino solo "un sentido referencial" (Blumenberg, 1981: 74) a las ideas. En el fondo, "lo que se llamará 'mundo del hombre [Welt des Menschen]' aquí no existe" (Blumenberg, 1981: 73).

Para Blumenberg, la depreciación aristotélica del cosmos noetós hace de la imitación y la técnica una determinación "de lo que puede ser hecho" (Blumenberg, 1964: 17). Platón había modificado en el Timeo su posición hablando de la posibilidad de la existencia de artefactos sin referencia a las Ideas, y Aristóteles daba cuenta de ello ${ }^{11}$. La imitación pierde su estatuto degradado, porque ahora el "arte es, de un lado, llevar a cumplimiento; de otro, imitación

${ }^{10}$ Puede verse un estudio a este respecto en H. Marín (1993). La antropología aristotélica como filosofía de la cultra. Pamplona: Eunsa, esp. 110-187.

${ }^{11}$ Cfr. Alejandro de Afrodisia. In Metaphysicam I, 9, 990 b 11, 79, 5-8. 
(de lo que se da en la naturaleza)" (Física II, 8, 199 a 15-17). Lo que el ser humano forja es lo que la propia naturaleza formaría (Blumenberg, 1955: 644 y sig.), y el ars imitatur naturam tiene entonces una justificación objetiva (Blumenberg, 1981: 56). "Techné y phýsis son principios constitutivos idénticos. El primero efectúa desde el exterior lo que el otro realiza desde el interior. La construcción se relaciona especularmente con el crecimiento" (Blumenberg, 1981: 73-4). Lo que intuye Blumenberg es que ese es el primer paso para la posterior escisión y contraposición de naturaleza y técnica, cuyo culmen es precisamente la comprensión de la técnica como control.

La concesión aristotélica desvinculante de la idea platónica, aunque sin acudir a la exégesis literal del propio Aristóteles, otorga a la physis un dinamismo que la técnica se apropiará como competencia propia. Esa dýnamis es precisamente movimiento, "la actualidad de lo potencial en tanto que potencial" (Física 201 b 5-6), tomando el tiempo como su medida, es decir, asumiendo el tiempo como el número del movimiento según el antes y el después.

Si bien esa es la definición kinética del movimiento, lo que Blumenberg apunta es que la tecnificación del mundo moderno hará que la kínesis se comprenda como ergón, desplazando el sentido mimético de lo técnico o artificial hacia el sentido temporal, y por extensión, el sentido temporal como control del movimiento. Cierto es que Aristóteles rastrea el movimiento en sus cuatro causas y hacia un motor inmóvil, pero lo que para Aristóteles sería inconcebible ahora se asentará sobre el uso (ya sin Aristóteles) de sus conceptos: técnica es tanto entelequia como movimiento perfecto, a saber, energeia (Metafisica 104630 y sig.). Ahora se puede decir que la techné es phýsis y su dýnamis: el motor del tiempo y el propio tiempo, y por extensión, del movimiento. Dicho de forma evidente para un contemporáneo: tecnología es el control de la energía que mueve la realidad.

Claro que eso ya no es Aristóteles, ni la cosmovisión griega o la medieval, pero es la reinterpretación moderna de algo que ni Aristóteles ni Platón eran capaces de vislumbrar: si la techné es physis y su dýnamis, entonces la técnica puede ser entendida como dueña del movimiento y su control. Y eso sí es una visión contemporánea, que la técnica es control del mundo, de su tiempo y su moverse. Lo que Blumenberg es capaz de ver es que la técnica como control 
exige y provoca necesidades y donaciones de sentido, de tal manera que es la respuesta del hombre "a su problemática específica con el ser [spezifische Seinsproblematik]" (Blumenberg, 1951: 462), porque la técnica presenta la existencia del ser humano como un hecho (Blumenberg, 1971: 114). Si la técnica se comprende como control porque desplaza a la metafísica, es porque ella se vuelve en sí misma metafísica.

La forma más preclara en la que se visualiza esa definición es justamente el discurso de las ciencias paleoantropológicas: el sapiens está en el mundo -su existencia se torna hecho- en su control del mundo. Es decir: existencia y técnica forman parte de una misma familia conceptual, porque ahora es el ser humano y su producción el que es, parafraseando a Aristóteles, "principio de movimiento y reposo", es decir, phýsis.

En ese sentido, la "idea", frente a Platón, está al servicio de la existencia, y por eso la paleoantropología ha devenido en el primer discurso sobre el ser del mundo y el ser hombre, al mostrar que la inteligencia no se dirige al cosmos noetós, o al motor inmóvil, sino a la propia existencia de lo humano. Dicho en términos paleoantropológicos: la cooperación instrumental y de tareas fue lo que nos hizo inteligentes, es decir, sapiens (Fuentes, 2017: 73 y sig.), así que lo técnico es la justificación primera y la causa última de nuestro existir.

Si lo primero respecto de lo humano ya no es la idea platónica ni el motor inmóvil -porque sus presupuestos se han vuelto irrelevantes al pensamiento contemporáneo-, esa priorización de la tecnologización como control se da bajo tres formas que corresponden justamente al control de tres movimientos. Y esos tres movimientos que requieren control técnico tienen relato paleoantropológico.

El primer movimiento que el ser humano necesita controlar es, precisamente, su propio movimiento: su cuerpo. Lo que le es dado por sí y para sí. Es un tipo de control que no es cronológica ni fácticamente fácil de lograr, sobre todo porque el cuerpo humano se relaciona con un equilibrio biomecánico que es más complicado (biomecánicamente al menos) que volar. Cuanto más control del movimiento corporal, más técnico es el movimiento. Frente a lo que se puede creer no es la adolescencia sino la larga y duradera infancia lo que distingue al sapiens de otros primates, "en cualquier otra especie de mamífero, incluidos los primates, las crías, a los pocos días de nacer, ya se 
alimentan por su cuenta y pueden correr o trepar [...]. Los niños humanos, no" (Campillo, 2007: 193). El bipedismo humano se caracteriza por una posición de equilibrio en la que se bascula sobre el arco del pie hacia el dedo gordo, redistribuyendo la cadera y la columna en una posición adelantada del foramen magnum del cráneo, es decir, estar de pie es estar en equilibrio, y moverse es más un aprendizaje de un movimiento no evidente en el que se usa la fuerza gravitatoria a su favor.

En el sapiens, frente a los primates cuadrúpedos, quedarse de pie y sin moverse mucho rato es molesto, porque sus apoyos son inestables o requieren de un control continuo. "Desde el punto de vista cinemático, la zancada se realizaría con la pierna y rodilla extendidas [no como en el caso de un bipedismo parcial e inseguro de los primates]. El ensanchamiento y reorganización de la pelvis reequilibra el centro de gravedad en la zancada, cuando alternativamente uno de los dos pies deja de estar en contacto con el suelo" (Rosas, 2015: 86). Así, el simple hecho de andar requiere de una educación y un control constante, dado por el core, el grupo muscular del glúteo y el cuello, que se equilibran mutuamente en cada paso. Algo parecido a lo que hacemos cuando se aprende ya con plena consciencia a controlar una bicicleta: basculamos el cuerpo en equilibrio para dar movimiento, y sin él la caída es inmediata.

Pero de todos los controles corporales motrices el más evidente en nuestro mundo contemporáneo, en su relación con la técnica, es el deporte: en cualquier deporte, el hecho de que un jugador tenga un mayor control del cuerpo mediante sus movimientos implica que tiene una buena técnica y cuanta más técnica tenga el jugador, mayor será el control de su cuerpo. Como dice Rafael Alvira, el deportista tiene que aprender su deporte mediante la práctica, es decir, la repetición inteligente, generando en su práctica, táctica y estrategia (Alvira, 1999: 52-3). Además, de su energía inagotable, es decir, de su capacidad de ejecución, muestra que cuanta más técnica tenga más energía podrá ahorrar y usar para su propio beneficio: jugar bien a cualquier deporte es tener técnica ${ }^{12}$.

\footnotetext{
${ }^{12}$ Tampoco, conviene precisar, Aristóteles entendió los juegos deportivos como modernamente los vivenciamos, es más, ni siquiera Ortega y Gasset -que era un firme defensor de la metáfora deportivaasumió el deporte como mera técnica del cuerpo.
} 
El segundo control se refiere al control del "movimiento de otro". Probablemente, el primer ejemplo histórico es la domesticación como el control del movimiento de los animales y de su energía ${ }^{13}$. La energía de un segundo control motriz es tardía en términos de la historia del sapiens y contiene sus propias diatribas: por ejemplo, ¿a qué se llama animal domesticado?, ¿se trata en la convivencia con un animal o la creación de una nueva raza?, ¿es la convivencia armoniosa y adaptada entre especies? El perro lo es desde hace 15.000 años; el ganado, muy posterior; llamas, gallinas, palomas, cabras, etc. Pero también animales que hoy generarían extrañeza, como gorriones, ratones, etc. La problemática de a qué se llama "domesticación" se puede ver en el caso de las abejas. En general, se muestra que la domesticación-como uso de una fuerza física motriz externa- adquiere relevancia en cierto modo de vida sedentaria ${ }^{14}$. Dicha domesticación (básicamente del neolítico) es proporcional al uso de la agricultura, al sedentarismo y al dominio de un último tercer control motriz. No obstante, este segundo control es la idea de externalizar el movimiento propio: se corre más rápido con un tarpán (caballo) que con los pies, se tiene más fuerza con un animal de porteo, como el uro euroasiático (res o vaca), que con los brazos, y lo mismo sucede con la disposición de comida que significa el animal domesticado (Larson y Fuller, 2014: 123), o la posibilidad de rastreo con un can. De hecho, como explica Francis, ningún animal que ha sido domesticado ha sucumbido a las extinciones climáticas o de diversa índole (Francis, 2015), mostrando precisamente el vínculo esencial de esa externalización motriz de lo humano hacia lo animal y anclando a este en la misma línea de supervivencia del propio sapiens: lo domesticado y lo humano corren la misma suerte, un mismo tiempo y un mismo movimiento.

El ejemplo más claro de esa relación entre tecnología, sedentarismo, fuerza motriz externalizada y domesticación se ve en las modernas tribus

\footnotetext{
${ }^{13}$ En la paleobiología, "la domesticación de las plantas" es posterior en varios miles de años a la de los animales.

${ }^{14}$ Una perspectiva general sobre las disputas zoológicas y la línea histórica de domesticación puede verse en Carlos A. Driscoll et al. (2009). From wild animals to domestic pets, an evolutionary view of domestication. Proceedings of the National Academy of Sciences of the United States of America (PNAS) (106), sup. 1, 9971-9978, esp. 9974 y sig. El estudio contempla Eurasia, pero no el continente americano o el oceánico.
} 
noramerindias, especialmente los Black Foot ${ }^{15}$, y en las tribus de las grandes planicies. No está del todo claro si las tribus precolombinas noramerindias, aunque más bien parece que no, tenían conocimiento del uso propio de la rueda. Sabían generar elementos circulares con ese formato, pero les faltaba la fuerza de tracción para darle el uso básico y propio que le daban los europeos, a saber, un caballo. No tener el dominio de caballos ni caballos es no dar sentido a la rueda ni tener rueda. Además de posibilidad, la tecnología puede definirse también como gestión y canalización de fuerza y energía (en este caso de tracción). Toda tecnología es la posibilidad de una nueva fuente de energía, tanto como de un nuevo modo, aunque parcial, de habitar el mundo. Tribus como los pies negros, y en general todos los (mal llamados) comanches o "tribus de las grandes llanuras", llamaron a los caballos bajo la forma en que entendían su fuerza motriz previa: $K^{\prime} k^{\prime} \bar{a}$ 't $\bar{a} Q \bar{Q} E t l t s i n$, "perro grande" o "perro-alce" (Brown, 1999: 4 y sig.).

El tercer control del movimiento -más visible y cercano al ojo contemporáneo- es sobre el movimiento de la naturaleza: construir un puente, un techo, usar un abrigo, regar un campo... son formas de "caminar sobre las aguas", controlar la temperatura corporal, evitar que la lluvia nos moje (o moje solo "interesadamente") o redirigir la corriente de un río. Que la naturaleza, el mundo, se vuelve campo de dominio y control es el tercer paso "natural" evidente de ese control técnico, cuyos efectos en el mundo contemporáneo se han generado descomunales bajo la rúbrica de "Antropoceno". Incluso la ciencia, como ha subrayado Latour, se ha transformado en el siglo xx en "tecnociencia" (Latour, 1992). Permita el lector que no se exponga aquí en demasía, ya que desde Marx y pasando por Adorno hasta Byung Yun Han, el dominio técnico sobre el mundo es no solo evidente sino problemático a nuestra contemporaneidad.

Parafraseando a Blumenberg, la tecnificación nace de la tensión entre el cometido de la razón, que se revela a sí mismo como infinito, y la capacidad de la existencia del hombre, que se nos da como constante. La técnica, decía Blumenberg, nos permite saltar (sprung) en vez de caminar, y así, cuanto más

\footnotetext{
${ }^{15}$ De los estudios más recientes al respecto, véase B. Bethke (2016). Differences Between Dogs and Horses: Transport and Mobility. Dog Days To Horse Days: Evaluating The Rise Of Nomadic Pastoralism Among The Blackfoot. University of Arizona, Proquest, tesis doctoral, esp. 106 y sig., y 151 y sig.
} 
tecnológica sea una cultura, mayor control sobre la naturaleza tendrá (con la consiguiente capacidad de dañarla o ayudarla), que es tanto como decir que mayor poder tendrá sobre su cauce y su tiempo (movimiento). Siendo la resultante última la equivalencia de destinos entre el dominio del mundo y el dominio del ser humano sobre sí mismo, es decir, uno y otro corren la misma suerte porque el mundo entero es ya dominio del hombre.

Los tres tipos de control están históricamente interconectados y no poseen carácter secuencial (primero lo primero, segundo lo segundo), sino intercomunicativo. Sin embargo, nuestra época será especial por la forma de entender la tecnología y también debido al hecho de que esa forma de entenderla no tiene precedentes desde un punto de vista histórico: no es un avance desde un estadio menos pulido, sino que será un salto cualitativo.

\section{§2. LAS BASES BÉLICAS DE LA TECNOLOGÍA: ARGUMENTACIÓN SINTÉTICA E HISTÓRICA}

Cabe, sin embargo, resaltar una idea relativamente oculta de esa tecnificación del mundo y que, aun siendo embrionaria y esencial, ha quedado relegada a segundo plano hasta prácticamente el siglo xx, para ser disimulada de nuevo en el XxI. Se trata de la relación de la tecnología y de sus técnicas con su carácter bélico. Aquí se ofrecerá una breve explicación sintética y otra histórica.

\subsection{Argumentación sintética}

Cuando Mary Shelley se hizo eco del mito de Prometeo en el subtítulo de su gran obra romántica Frankenstein, estaba poniendo de relieve lo que la técnica en ese momento solo adivinaba como ficción pero deseaba como proyecto: ¿qué sucedería si la técnica y la ciencia otorgasen la inmortalidad y la victoria sobre la propia naturaleza? "La gloria que podía alcanzar, dice el doctor Frankenstein, si conseguía liberar a la humanidad de todas las enfermedades, haciendo del hombre un ser invulnerable a cualquier tipo de muerte". 
Para Shelley, sin embargo, el efecto no era un esperado mundo libre y feliz, sino, como le hace decir a la criatura: “PPor qué tenía yo que ser bueno y tolerante con quienes eran mis enemigos encarnizados? Desde aquel instante me declaré en guerra constante contra todo el género humano".

Lo que Shelley no entrevió, así como muchos comentadores del mito platónico, es que Platón ya anticipa que la técnica no era solo posibilidad del mundo y de lo humano, sino su propia lucha. Es el propio Platón el que toma el registro belicoso para describir cómo Prometeo y Epimeteo:

A unos [animales] les concedía la fuerza sin la rapidez y, a los más débiles, los dotaba con la velocidad. A unos los armaba y, a los que les daba una naturaleza inerme, les proveía de alguna otra capacidad para su salvación. A aquellos que envolvía en su pequeñez, les proporcionaba una fuga alada o un habitáculo subterráneo. Y a los que aumentó en tamaño, con esto mismo los ponía a salvo. Y así, equilibrando las demás cosas, hacía su reparto. Planeaba esto con la precaución de que ninguna especie fuera aniquilada. Cuando les hubo provisto de recursos de huida contra sus mutuas destrucciones (Protágoras 320 e, 1-5).

De hecho, la concesión del fuego de los dioses, su condición divina e inteligente, no es de suyo suficiente para la subsistencia. El ser humano "estaba desnudo y descalzo y sin coberturas ni armas" (Protágoras $321 \mathrm{c}$ ), e incluso con el dominio del fuego, los hombres "se veían destruidos por las fieras, por ser generalmente más débiles que aquéllas; y su técnica manual resultaba un conocimiento suficiente como recurso para la nutrición, pero insuficiente para la lucha contra las fieras. Pues aún no poseían el arte de la política, a la que el arte bélico pertenece".

Si la polis es una de las cosas naturales (cuyas leyes metafóricamente "paren" a los ciudadanos) o es phýsei según Aristóteles, cabe decir que en ambos autores la política incluye de suyo la polémica (guerra). Como bien dice Valderrama, explicando la tesis de Julien Freund, "dado que la paz no excluye al enemigo, sino que precisamente lo incluye al no poder hacerse más que con él -negarle vendría a ser de facto impedir la paz-, cuanto se le pide a la política no es extirpar de raíz las condiciones de toda enemistad, sino en todo caso su civilización, tomando las medidas necesarias para que los conflictos sociales 
no degeneren en conflictos públicos, o para que si toman esta dimensión, al menos se les busque una solución satisfactoria. Es el que llama Freund, «el significado elemental [minimale] de la política»" (Valderrama, 2017: 125). La política no es desde luego y no solo polémica (polemós), guerra, sino la propia posibilidad de la gestión de la concordia la convierte también en agón, esto es, como gestionadora in pectore de todo conflicto.

Así, puede decirse con naturalidad que toda subsistencia implica una tecnología bélica, y que, sin la segunda, la primera es de suyo inviable. Bien es cierto que la guerra no es núcleo de la posibilidad política, sino que es una de sus acciones necesarias, $\mathrm{y}$, por lo mismo, la guerra se hace respecto de otras polis y no respecto de la mera subsistencia física o respecto del gobierno de la ciudad (cuya distinción se clarifica en la distinción griega entre agón y polemós). Y, por eso, solo los ciudadanos, y los aristós, y no los esclavos, hacían la guerra, porque hacer la guerra es asunto público (res publica).

Lo que los modernos y Aristóteles afirman no es que la guerra es pura y netamente técnica según el modo en que la técnica se ha vuelto autónoma -tomando esta según su sentido protésico de "artefacto", o tan "artefacto" como lo es el Estado para Hobbes o Rousseau como padres de la filosofía política moderna-. Aristóteles ve la guerra como una de las funciones del político, así que guerrear es continuar en cierta forma uno de los modos -aunque no el único ni el primordial- de dar cumplimiento perfectivo a la naturaleza política, y, por extensión, al aristós.

Solo los libres participarán de la guerra como tales guerreros, y que la guerra misma fuera el ejercicio eminente de la libertad, signo y causa de la condición de libre, de ciudadano. Aquiles es el héroe campeón de esta clase de libertad, pues no solo es invencible y el mejor, sino que abandona placeres adolescentes y acude a la guerra a sabiendas de que perderá la vida si bien ganará la gloria. Jugarse la vida a sabiendas de que se va a perder, aunque sea en el intento de evitarlo, es disponer de sí con la mayor radicalidad y, por tanto, llevar a su plenitud la clase de posesión en la que consiste la libertad [en la Grecia homérica] (Marín, 2019: 284-5).

Así, si se toma la técnica en su versión de control y dominio, tanto Ortega como Heidegger saben que la técnica, frente al optimismo parcial y sesgado 
de la modernidad, está asociada tanto a la posibilidad del mundo como a la necesidad, y, concretamente, a "la satisfacción de las necesidades -dice Ortega-, por lo pronto, elementales" (Ortega, 1983: 333). Ese es el sentido por el que se podría decir que no ha habido mucha más técnica ahora que hace miles de años. Quizás menos tecnologías y más rudimentarias, pero no más en cuanto lo que significa la técnica para el ser humano y el mundo.

Si es así, el fuego comparece entonces no solo como la posibilidad de luz, sino como la posibilidad de comer de determinado modo, es decir, como la satisfacción de una necesidad. Pero si se sigue la argumentación, y tomada la técnica como posibilidad del mundo y de su dominio, entonces el propio fuego es arma y defensa. Un carácter bélico también compareciente en el relato paleoantropológico, pues "pese a la supremacía tecnológica que cacareamos y que nos convierte en el mayor depredador de nuestros días, aún no hemos superado del todo los puntos vulnerables de nuestro pasado remoto. Cualquier corredor que haya sido atacado por un puma o un tirador de arco que se haya visto obligado a subirse a un árbol para escapar de un oso estarán de acuerdo. El fuego había constituido un medio excelente para disuadir a los carnívoros en aquella época, sobre todo si tenía que subsanar la limitada habilidad para el lanzamiento de objetos que suponía la articulación del hombro rotada hacia delante" (Tattersall, 2012: 160).

De ese modo, el lugar de la subsistencia y la cobertura de necesidades se amplifica en potencia dañina bajo dominio de la naturaleza. Dicho de otra forma: comer y matar y ser señor del mundo comparecen en el mismo lugar, y, por eso, si se toma la mano del sapiens como la fisionomía básica del dominio técnico, entonces "funcionalmente la especie humana tiene los dientes en las manos, y casi se puede decir que las primeras herramientas humanas son prótesis dentales, indiscerniblemente armamento y cubertería, porque ambas son las misiones de los dientes que hay que llevar a cabo en la mano" (Marín 2019: 408), y esto es lo que "el hombre experimenta desde el principio, su supervivencia como pendiente de la clase de exterioridad que son la técnica y la civilización" (Marín, 2019: 409).

Ese carácter concausal de "posibilidad de la vida" y "necesidad de la guerra", de nutrición y muerte, es lo que está detrás -aunque de forma exacerbada y muy matizable- de la tesis del famoso primatólogo Richard Wrangham 
(Wrangham, 2019). Para Wrangham, una especie de "guerra" fue uno de los comportamientos específicos que nos hizo sapiens. Wrangham afirma que el homo se convirtió propiamente en sapiens al matar al individuo alfa dominante para poder vivir en paz. Es lo que Wrangham llamó "agresión proactiva" (planeada, meditada, con un objetivo, con reglas...), frente a la "agresión reactiva". Pero aquella protoguerra de la que Wrangham habla y que nos hizo sapiens no solo necesitó de una colaboración, sino también de cierto orden tecnológico, al menos, en tanto que control del movimiento del otro y por supuesto en el comer y la subsistencia, y por eso, casi de forma espontánea, la segunda tesis de Wrangham sobre la sabiduría del sapiens es el uso del fuego en el comer (Wrangham, 2009).

Ciertamente, la tesis de Wrangham es matizable en muchos niveles, pero como dice Choza una de las formas basales en las que el hombre toma conciencia de sí, de la posibilidad de su vida y de su existir en el mundo, es su conocimiento de que hay que matar para vivir, es decir, en la toma de conciencia de la expresión clásica y religiosa: "tener las manos manchadas de sangre". Mas el proceso civilizatorio consiste también (aunque no solo) en transformar y canalizar "la agresividad y la violencia [...] en una virtud [política] a la que los griegos llamaron andréia, los romanos fortitudo" (Choza, 2013: 28), y que con los siglos adquirirá rostro propio al margen de su nacimiento bélico.

\subsection{Argumentación histórica}

"Igitur qui desiderat pacem, praeparet bellum" era la cita de Vegecio en su De rei militari: "quien desee la paz, que se prepare para la guerra". Pero eso hace de la paz algo a lo que la guerra no le hace justicia, a saber, efecto e hija de aquella. Si la técnica es dominio y poder sobre el mundo, como la metáfora del fuego lo era, también es el control de su movimiento, y, por extensión, de sus límites. La lucha es la potencia del sujeto (posibilidad) respecto de los límites del mundo, así que el imperio bélico es el imperio sobre los territorios en los que el ser humano puede, literalmente, moverse. De otro modo: la guerra es también conquista sobre la naturaleza en su sentido más espacial. 
Si técnica es control del movimiento, es también y por efecto la inauguración de su límite, es un "hasta aquí hemos llegado" y un vita in motu por el mundo: el mundo es el lugar donde el ser humano puede poner sus pies, es decir, llega. "Poder poner un pie" -moverse, ir y llegar- es la conquista del lugar, tanto como paleoantropológicamente "ponerse de pie" es la conquista del cuerpo propio. Así que, en términos bélicos, es verosímil aceptar como hipótesis que las grandes potencias tecnológicas han sido grandes potencias bélicas, $\mathrm{y}$, por extensión, sus belicosidades han gestado los modos del movimiento. Dichos modos de moverse serán el motu in terra y el motu in mares, moverse por mar y tierra, teniendo como consecuencia natural que tierra y mar serán al mismo tiempo los límites del mundo (al menos hasta el siglo $\mathrm{XIX)}$.

La idea de que la tecnología náutica es la tecnología que marca, más literal que figuradamente, el límite del mundo se observa en las manifestaciones culturales de los enterramientos guerreros y heroicos. Si este "mundo" es límite y frontera con otros, resulta natural que la acción de aproximación a ese límite metafísico sea también cultural y simbólicamente náutico: el mar es límite y también frontera de este mundo con otros mundos. Eso son los enterramientos egipcios y sus barcas ${ }^{16}$, el barco de Caronte, o los enterramientos escandinavos con sus barcazas ${ }^{17}$. A la muerte, límite fronterizo de lo humano, se llega metafóricamente por el modo técnico por el que el hombre se mueve en dichos límites: un barco.

Los primeros héroes náuticos serán homéricos y de la Hélade: Jasón, los argonautas, pero sobre todo Ulises, que es el héroe de la técnica y la astucia, y, por tanto, de la navegación ${ }^{18}$. Ulises, el héroe de la Odisea, se entiende como

${ }^{16}$ Se trata de la famosa "barca solar" o "barca funeraria de Keops". La primara nave funeraria está datada en 2500 a. C.

${ }^{17}$ Lejos de la creencia popular de las piras de los barcos en los enterramientos del "nord-men" (mal llamados vikingos: piratas de la bahía), el enterramiento en túmulos era lo habitual. Uno de los más conocidos, sito en Noriega, es el de Oseberg, donde el "ataúd" es un barco. Véase Walaker (2011).

18 "El divino Ulises desplegó su velamen; sentado rigió con destreza el timón; no bajaba a sus ojos el sueño, velaba a las Pléyades vuelto al Boyero de ocaso tardío y a la Osa, a que otros dan el nombre del Carro y que gira sin dejar su lugar al acecho de Orión; solo ella de entre todos los astros no baja a bañarse al Océano. La divina entre diosas, Calipso dejó dicho a Ulises que arrumbase llevándola siempre a su izquierda". Odisea, Canto V (269-277). 
un hombre que controla la tecnología más avanzada de ese momento: la navegación a través de los convulsos mares. Ulises no es un héroe porque es un guerrero rápido (como Aquiles) o fuerte (como Ajax o Hércules), es un sujeto que posee la habilidad de controlar los problemas relacionados con la guerra (como las maniobras militares), y por esta razón es un buen estratega (él es el inventor del caballo de madera). Si es así, no es extraño que Ulises sea un superdotado tecnológico para su época, y su inteligencia, su arma. Su apodo da nombre a su heroicidad: "el astuto Ulises". Por lo mismo, se ajusta bien que Ulises fuese representado en la Odisea como un individuo que controla el movimiento tecnológico más avanzado en ese período y que Éolo le concediese el poder de controlar los vientos: ser un gran marino significaba ser tecnológicamente avanzado, y su correspondencia en la astucia de la guerra es casi una continuación natural de sus habilidades náuticas (Choza, 1998). Sin dominio del movimiento no hay posibilidad de ir a Troya.

Grecia y su flota, sus navegaciones y sus destrezas son la posibilidad del mundo, y también de sus guerras. Como explica Keegan en su clásico Historia de la guerra, las guerras entre persas y griegos (Jerjes, Darío, Atenas, Esparta) fue un conflicto entre dos contrarios, "representados por el poder terrestre y el poder marítimo" (Keegan, 2004: 348).

Pero lo mismo pasaba con el Egipto faraónico: el Nilo es el lugar primero de dominio de lo terrestre: "Mientras el ejército de Hefat está en calma, toda la tierra está en calma; pero si uno (le pisa) la cola como (la de) un cocodrilo, entonces el norte y el sur tiemblan (de miedo) [...] Navegué corriente abajo con fuerte y fiable tropa y amarré en la orilla occidental del nomo tebano", cuenta Ankhtini durante la VI Dinastía (citado en Shaw, 2007: 174). Ese poder náutico como poder decisivo se mostró también en la famosa batalla de Ptolomeo en Salamina (Shaw, 2007: 521). Y algo similar fue la potencia militar del pueblo escandinavo con una tecnología que era capaz de hacer navegar grandes barcos tanto a mar abierto como en cauces fluviales (Price 2020, 218-19), y que hizo tambalear durante siglos varios imperios: "embarcaciones adecuadas para la defensa y la navegación costera o por los fiordos, y drakares que eran capaces de navegar por alta mar, participar en grandes expediciones de saqueo y librar una auténtica guerra marítima" (Price 2020, 220). 
No obstante, fue Roma el lugar y el imperio donde esta idea de la tecnología como control del movimiento y, por extensión, del límite del mundo tuvo una forma más evidente. Roma da control (y por extensión poder) a sus legiones en la canalización de su movimiento terrestre, inventado para ellas algo inaudito en la época: un sistema de caminos cuyo aseguramiento se daba por su pavimentación: las calzadas o vías. "Las legiones romanas mostraron una gran capacidad de marcha, cubriendo mucha distancia a paso regular” (Keegan, 2014: 361).

Para mantener un imperio tan grande se necesita ahorrar energía, y eso significa (según las ideas que se mencionaron más arriba) la creación de nuevas formas de moverse, nuevas tecnologías, y encontrar maneras de ahorrar tiempo y aumentar el control. Los romanos eran tan buenos soldados como ingenieros, $\mathrm{y}$, de hecho, por ser lo segundo, eran también lo primero.

La primera manera de lograr una "conservación de la energía" fue construyendo una increíble red de carreteras (pavimentadas) en toda Europa. Red de carreteras creadas sobre todo para los movimientos de las legiones romanas. Gracias a esa ingeniería de caminos, pudieron mover tropas fácilmente de un lugar a otro cuando la situación lo requería y, por lo mismo, optimizar su energía militar (Keegan, 2004: 357 y sig.). Algo tan aparentemente simple, pero no evidente, como pavimentar un camino hizo que "las calzadas [se convirtieran] en un claro ejemplo de una obra [de ingeniería] construida de forma lógica y bien adaptada a su fin, en un principio estrictamente militar" (Ponte, 2007: 32). Incluso en el derecho romano, el movimiento de las legiones tenía prioridad sobre cualquier viandante o caravana comercial. Era imposible cubrir y gobernar semejante territorio sin una tecnología que permitiese un rápido movimiento terrestre.

En ese sentido, la estrategia militar se hace eco de una de las definiciones de técnica de Ortega y Gasset: "la técnica es el esfuerzo por ahorrar esfuerzo". Es la forma en que establecieron la famosa Pax Romana. Pax Romana fue un período de paz creada sobre todo por la forma en que los romanos trataban (hacían tratos) con sus enemigos. La idea original era ahorrar "energía", es decir, soldados y recursos militares. Por lo tanto, el plan era enfrentarse a los enemigos siempre a través de los tratados, que eran una especie de "paz bajo amenaza". La contienda abierta es siempre el último recurso, ya que, por así decirlo, en ella se emplea una gran cantidad de "energía" y tiempo (soldados, maquinaria, tracción animal, intendencia, etc.). No hay muchos 
ejemplos en las guerras de la Antigüedad donde el objetivo fuese destruir ciudades o reinos completamente. De hecho, muchas de esas batallas se llevaron precisamente fuera de las ciudades, lo que dio lugar al concepto de "campo de batalla", es decir, no en la polis, no en la civitas.

A través de la historia, todos los grandes imperios han sido tecnológicos en sus ejércitos de un modo u otro: por mar y tierra, flotas e infantería capaz de moverse también con esas flotas ${ }^{19}$. Pero el mar seguía siendo el límite del mundo, el lugar del movimiento más puntero, más tecnológico, más avanzado, y, como reza el poema, su confín. Podemos resumirlo de esta manera: los imperios más poderosos hasta el final del siglo XIX tenían poderosas flotas y grandes capacidades de maniobrabilidad terrestre. Eso es la dominación durante siglos del Imperio español (hasta principios del s. XIX), y desde el siglo XVII hasta el XX con el Imperio británico.

Sin embargo, las tecnologías van a cambiar durante el siglo XIX con la nueva Revolución Industrial, y cabe advertir al lector de que la consecuencia propia es que EL mundo y su posibilidad cambiarán con ellas.

\section{$\S 3$. LAS NUEVAS TECNOGUERRAS: EL SIGLO XIX COMO INICIO, EL XX COMO EXPLOSIÓN}

La Revolución Industrial es la primera etapa, gestante aÚn, de una nueva era tecnológica. En términos militares, uno de los mejores ejemplos es la invención del revólver Colt -cuyo mecanismo patentó el coronel unionista Samuel Colt y fue llamado Six Shooter-. De repente, un arma multiplica por seis el poder de un solo soldado (es sintomática su traducción porque es "seis tiradores" y no seis disparos), de tal modo que, si técnica era energéia, ahora se ha multiplicado de un modo imprevisible. Como muestra Keegan, el uso y control de la pólvora supuso una revolución nunca antes vista en términos bélicos, o dicho en nuestro uso: "potencia de fuego" (firepower). Pero junto a ese incremento de energía mediante la técnica se confabula en el revolver

${ }^{19}$ En el caso del Imperio español, fueron famosos sus tercios, pero también su infantería de Marina, que en la guerra de todas las guerras (la Segunda Guerra Mundial) tuvo una copia en la creación estadounidense de los "marines". 
el ser la primera arma de producción en masa, en otras palabras, la primera dentro de un proceso industrial de fabricación para armas de fuego. Es el incremento inaudito y multiplicador de la "potencia de fuego" y de la recreación de una nueva energía nunca antes vista.

Es el siglo XIX el que empieza a entender, amparado por la Revolución Industrial naciente, no la guerra como victoria, sino la guerra como eficacia. Un heterodoxo neomarxista como Morris denuncia, en la Revolución Industrial, que "hay un tipo de productos que no siguen la tendencia del sucedáneo [que Morris critica]. [...] La fabricación de instrumentos para destruir riqueza y asesinar hombres, [...], la guerra, [y] la enorme cantidad de máquinas herramienta" (Morris, 2016: 109). Todo medio bélico se entiende "como medio de una victoria", pero el medio se mide por su conveniencia: no por su honor, no por su justicia, no por su proporcionalidad y mucho menos no por su legalidad. Como explica Henández-Pacheco, la creación en el siglo XIX de lo que será el "Estado mayor" para la guerra implica una instrumentalización de lo bélico en la que se considera la victoria como la "aniquilación de los vencedores igual que de los vencidos" (Hernández-Pacheco, 2008: 32). Vencer es ya solo puro dominio, aunque implique la destrucción total.

Esa nueva era tecnológica va a experimentar su gran empuje en la Primera Guerra Mundial, pues en ella se verá el comienzo de nuevas tecnologías (primeros tanques, aviones, la revolución química y bacteriológica con gases...) luchando, sin embargo, contra los métodos de los viejos ejércitos (caballería común, infantería básica, etc.). Un medio tecnobélico que se ha generado tan omnívoro que no se ha sabido aún asimilar ni usar como medio. Esa desproporción todavía no culturalmente digerida inaugurará una guerra nueva: la guerra de trincheras. Las trincheras son, en el fondo, fortificaciones móviles. Casi como un fuerte que ha de poder cambiarse de lugar. Sin embargo, antes que una invención, las trincheras fueron un recurso de fortuna ante unas tecnologías contra las que no se sabía cómo lidiar. Las cargas de infantería -tan habituales desde siglos atrás- eran casi inútiles contra las nuevas ametralladoras y morteros. Los caballos (en un tiempo la gran potencia tecnológica militar) eran blanco obvio y fácil. No saber qué hacer ante ello significó estar parados a esperar, es decir, cobijarse en una trinchera. Y la propia dificultad de no saber lidiar con esos nuevos inventos originó el descubrimiento de un 
territorio baldío: un nuevo "campo de batalla" (battlefield) llamado "tierra de nadie", es decir, el yermo entre trincheras enemigas. El final del siglo XIX y el principio del xx es el momento del desconcierto máximo entre vida y técnica, cuya explosión incontrolada será la Segunda Guerra Mundial (Comellas, 2000: 250 y sig.)

La Segunda Guerra Mundial verá la llegada de nuevos tipos de batalla que son proporcionales a los nuevos tipos de movimientos tecnológicos: la batalla del Atlántico (submarinos), la batalla de Inglaterra y los bombardeos tácticos (aviones) y los nuevos movimientos terrestres (tanques) (Beevor, 2012). El mundo se ha ampliado tecnológicamente por tierra, mar y aire: porque nos movemos por tierra más rápido que nunca, porque podemos ir bajo el agua y porque el aire se ha conquistado. Nuestros actuales automóviles, aviones o barcos comerciales son los descendientes de esos tanques, barcos y aviones. Incluso la inteligencia artificial (gracias a Alan Turing) debe algo a esa guerra. Muchas fábricas, como Volkswagen, BMW, Porsche, Harley Davidson, Ford, Rolls and Royce o Yamaha, fueron los principales desarrolladores durante esa guerra de muchas investigaciones tecnológicas.

A pesar de todo esto, estas nuevas tecnologías y nuevas formas de moverse (por lo tanto "más control") son todavía muy inexactas y las estadísticas muestran un gran y siempre creciente número de víctimas civiles y soldados durante la Primera y la Segunda Guerra Mundial. Estos datos son alarmantes y corresponden a ciudades enteras que fueron destruidas. Antes del siglo $\mathrm{xx}$, las ciudades eran en su mayoría lugares sitiados y dejados intactos. Los campos de batalla eran precisamente eso, campos, ya que la idea era para proteger a los civiles del lugar de la contienda y porque la ciudad era el botín por conquistar. Grandes batallas como Stirling o Gettysburg tuvieron lugar lejos de los núcleos urbanos. Incluso la Primera Guerra Mundial se libró en las trincheras. La ciudad no es lugar para la guerra, quizá para la revolución, pero no para la guerra. Todo esto cambiará en la primera mitad del siglo pasado. Los rápidos avances en la tecnología contribuyeron a perpetrar matanzas bárbaras de una crueldad nunca antes vista. Aunque los números de víctimas en las guerras mundiales están aún en disputa, los académicos calculan las bajas de la Primera Guerra Mundial entre 10 y 31 millones. Las de la Segunda Guerra Mundial estuvieron entre los 70 y 83 millones (incluida la guerra entre 
China y Japón, que comenzó en 1937). Sin embargo, en lo que no hay discusión es que todos los historiadores, independientemente del corte ideológico que sean, han declarado ambas guerras como las más crueles y bárbaras en la historia de la humanidad.

¿De dónde proviene tanta crueldad? Aunque no existe una respuesta única para una pregunta de tal calado, cabe decir, en lo que incumbe a la temática, que si la tecnología significa control, podríamos agregar la idea de que el control de cualquier movimiento también es un tipo de precisión ${ }^{20}$. Este tipo de precisión no estaba todavía listo en ese momento. El mejor ejemplo es el bombardeo aéreo en la Segunda Guerra Mundial, donde innumerables ciudades fueron casi totalmente destruidas. Por no mencionar las dos bombas atómicas. Ese tipo de inexactitud y falta de control son impensables hoy en día, y es fácil de entender a través de la acuñación de un concepto militar más reciente: el "daño colateral". Más precisión y control indica un menor daño colateral, es decir, a mayor tecnología del movimiento menor debe ser el daño colateral que conlleva, pues la precisión ha de verse proporcionalmente aumentada. Ni que decir tiene que dicho concepto no fue usado ni dicho durante las guerras mundiales. Serán precisamente esas guerras y su carácter demoledor la inauguración conceptual que propicie dicho concepto.

Por todas estas razones, uno de los botines más codiciados después de la Segunda Guerra Mundial por los aliados fue la distribución de los principales científicos alemanes. Habían inventado y desarrollado como nadie una nueva forma de movimiento: el combustible líquido y el misil V2 (Vergeltungswa$f f e$ 2). Y quizás por esta razón la nueva navegación después de la Segunda Guerra Mundial se definió como una especie de lucha entre las potencias enemigas: la carrera espacial y sus naves, que, como es bien sabido, ya no eran barcos sino naves (veleros) espaciales. De hecho, el misil V2, de invención alemana, fue el primer objeto que hizo un vuelo suborbital en la historia, es decir, el primero en abandonar la atmósfera de la Tierra. No fue un satélite, ni un avión, ni fue el deseo de mirar las estrellas lo que motivó su creación: el

${ }^{20}$ Es notable la diferencia del sentido de precisión según la técnica bajo un modo autónomo, es decir, automático, y según la "técnica del cuerpo". Para esta última, véase A. Serrano de Haro (2007). La precisión del cuerpo. Madrid: Trotta. "La actividad de precisión que es el lanzamiento de proyectiles distingue a la especie humana" (Serrano de Haro, 2007: 99).

SCIO. Revista de Filosofia, n. ${ }^{\circ}$ 20, Julio de 2021, 25-61, ISSN: 1887-9853 
primer objeto que los hombres enviaron al espacio fue un misil balístico. Hoy en día enviamos datos vía satélite, pero lo primero que los humanos enviamos al espacio, como las naves del Imperio romano, fue nuestra artillería pesada. Si la tecnología es capaz de llegar a lugares previamente inexplorados, dando paso a un nuevo tipo de movimiento, no es extraño que la carrera por el espacio se convirtiera en militar y fuera un problema estratégico para la Unión Soviética y Estados Unidos.

Estados Unidos comenzó esta carrera con su fuerza aérea y los pilotos de jets, pero pronto creó una nueva agencia civil con financiación militar diseñada expresamente para ganar esa batalla: NASA, fundada por el presidente y el excomandante de las fuerzas supremas aliadas en la Segunda Guerra Mundial Dwight D. Eisenhower.

El mundo ya no tenía los límites del mar sino del espacio. Las naves ya no surcaban los océanos sino las estrellas. Y las guerras iban a ser tan distintas como nuevas eran las tecnologías y los movimientos que proveían ${ }^{21}$.

\section{§4. De LA GUERRA AL SALÓN: LAS GUERRAS MEDiÁticAS}

Después de la Segunda Guerra Mundial, los años sesenta y setenta serán los años de la nueva producción industrial y de la expansión de las tecnologías militares a las domésticas en tiempos de paz. Es la idea de la "Gran América", o de la "Francia gloriosa", o de los modelos socialdemócratas escandinavos. También son las décadas de los inicios del estado de bienestar en la reconstrucción de Europa y de la dominación mundial de EE. UU. como el país más poderoso. Las invenciones militares se convirtieron en dispositivos domésticos: TV, radio, neveras, lavavajillas, las nuevas tecnologías de nutrición, ropa, coches, líneas aéreas...

Entre todas estas tecnologías, debemos subrayar tres: La electricidad entendida como la capacidad de iluminar la oscuridad; la voz, entendida como

\footnotetext{
${ }^{21}$ A todo ello cabe añadir la guerra, cuya energía no podía ser dominada y, por tanto, no podía ser declarada: la guerra nuclear.
} 
la capacidad de escuchar en la distancia; y la imagen, entendida como la capacidad de ver en la distancia.

A fuerza de simplificar, se puede decir que estas tecnologías son la oportunidad de vivir no solo el presente empírico sino también de ver, oír y experimentar una realidad que ni siquiera está empíricamente cerca de nosotros. Teléfonos, radios y televisiones son los primeros ejemplos de todo esto, equipos ya integrados en las salas de estar de muchas casas durante los años sesenta y setenta.

Sin embargo, una nueva "guerra" revelará este nuevo panorama tecnológico "no presente": la guerra de Vietnam (guerra en la que, a propósito, se empezó a acuñar el término "daño colateral", en relación con la necesidad de precisar la "potencia de fuego"). Y es que fue la guerra de Vietnam el momento en que "las democracias Occidentales fueron altamente sensibles [por primera vez] a los porcentajes de bajas entre sus fuerzas armadas e hicieron grandes esfuerzos por minimizarlas" (Cronin, 182), no previendo la desproporcionalidad con las bajas de civiles.

Lo sintomático era que, a pesar del hecho de que la Primera y sobre todo la Segunda Guerra Mundial fueron las guerras más crueles en la historia, por el número de muertos y la destrucción, fue la guerra de Vietnam la que se convirtió en un punto de inflexión. Civiles ordinarios sentados en sus casas van a ver por primera vez en la historia una guerra emitida en directo desde la televisión de su salón. La atmósfera pacífica y de bienestar que disfrutaban las sociedades occidentales se verá interrumpida por nuevas imágenes y sonidos que eran enormemente bárbaros en este nuevo período tecnológico. El mejor ejemplo es la famosa fotografía de Nick Ut.

Para los estadounidenses era casi insoportable ver las imágenes de ese tipo de guerra salvaje. Nick Ut pudo capturar la brutalidad y crueldad de esa guerra. En su más famosa imagen hay una niña aterrorizada desnuda que, junto a otros niños, corre desesperadamente para escapar de las bombas de napalm (Hariman y Lacaites, 2007). ¿Cómo era posible que, en una nueva era tecnológica caracterizada por el dominio sobre la naturaleza (el hombre había llegado a la luna y aquellos tanques que sustituyeron en su momento a caballos, ahora se habían transformado en poderosos helicópteros) y el control 
preciso del movimiento, se diese una guerra tan cruel? Muchos sociólogos entendieron esto como un problema emocional de la cultura de ese momento.

El mismo tipo de precisión que disfruta el público en sus recientes hogares tecnológicos es el que se requiere para las emociones y también para cualquier tipo de guerra. El ejército estadounidense fue la armada del país más tecnológico y poderoso del mundo que perdió una guerra en medio de la jungla. Era una desproporción incontrolada. Lo curioso es que esa reacción del público no se había dado ni en la Segunda ni en la Primera Guerra Mundial, que son, con mucho, las guerras más sanguinarias, no solo del siglo Xx sino de toda la historia de la humanidad. ¿Qué había pasado? ¿Cómo había influido la tecnología para semejante reacción de rechazo social?

Los civiles estadounidenses que habían servido como soldados durante la Segunda Guerra Mundial, pero, sobre todo, los hijos de estos, es decir, aquellos que ya habían nacido al calor de esas tecnologías domésticas, asumieron tres características de esta nueva era tecnológica:

1. Las imágenes ya no eran externas a sus vidas (las imágenes estaban moldeando sus vidas, como la fotografía de Nick Ut, grabada para siempre en la retina): la imagen les había permitido "moverse" por mundos y continentes nuevos.

2. La precisión adquirida ahora con la tecnología doméstica era un requisito que también se pedía en las batallas.

3. Por lo mismo, las imágenes también adquirieron esta precisión emocional que el sujeto requería para su vida diaria.

Así, el mismo control que la tecnología poseía ofrecía ahora al individuo un tipo de control para que pudiera disfrutarlo en su vida diaria personal. Además, la industrialización tecnológica ya no era un "medio" para lograr algo en la realidad, sino que la tecnología estaba tratando de ser la realidad misma bajo la forma de imagen precisa y controlada. En ese momento, la imagen representada en la televisión (hoy en día se encuentran más a menudo en nuestros móviles) era cada vez más real, y de una realidad que permitía un control mayor que el de la realidad empírica y, por lo tanto, tan confortable como la sociedad del bienestar en la que se vivía: ¿cómo era posible ver una guerra en 
la jungla? Dicho de otra forma: las imágenes empezaban a ser más reales que la realidad empírica cercana (zuhandenheit: lo "a la mano") porque lo que se emitía en un medio tecnológico virtual -signo del poder y control humano respecto de uno, respecto de otro y respecto de la naturaleza- era el culmen del habitar humano. Más aún: solo cuando la realidad tecnológica certificaba un hecho era cuando podía declararse como real, porque esa tecnología era la piedra miliar de nuestra humanidad en su posible destrucción o en su creatividad. Aquellas famosas declaraciones de Muhammad Alí cuando se negó a ir a la guerra - ¿¿Por qué me piden ponerme un uniforme e ir a mil millas de casa y arrojar bombas y disparar balas a gente...?"- son proporcionales a la idea de poder saber y ver con sorprendente y nueva exactitud lo que pasa a mil millas de la casa de uno.

La guerra de Vietnam fue, entre otras muchas cosas, una guerra cruel, pero sobre todo emocionalmente insoportable para el público estadounidense. El mero conocimiento de una guerra en curso no era estrictamente el problema, es decir, el conocimiento no es la causa principal de esa insoportabilidad. El público casi no recordaba los bombardeos de la Segunda Guerra Mundial, pero en ese momento estas nuevas tecnologías eran todavía como un niño recién nacido. La guerra de Vietnam es la heredera de esa guerra, donde las imágenes, las voces y todos los dispositivos eléctricos son en ese momento parte de la vida de las personas. Tras las dos grandes guerras, el ser humano había incorporado lo que siempre había hecho desde sus inicios: asumir la tecnología bélica en tiempos de paz. Los movimientos se habían generado con tal potencia que el mundo se abrió y se ensanchó hasta puntos insospechados.

Sin embargo, el factor crucial de la insoportabilidad de la guerra de Vietnam no es lo que el público sabe, sino lo que el público ve y, lo más importante, lo que da forma a sus vidas es una imagen que no es parte de su situación empírica; pero es que ahora su situación empírica, y esto es el quid, empieza a ser sustituida por la imagen que ellos tienen de sí mismos y no únicamente por la imagen que de otros se les ofrece. "El desarrollo tecnológico y mediático que habían alcanzado los países desarrollados, y en particular Estados Unidos de América, los había deshabituado y, por tanto, inhabilitado para poner a salvo la estructura biográfica personal de la defunción frecuente de los allegados, mientras que esa era precisamente la orografía sentimental y 
social que habitan los hombres de la antigua Indochina. La guerra de Vietnam se perdió [también] por razones sentimentales, es decir, por desajustes entre las tecnologías del daño que fue forzoso utilizar" (Marín, 2010: 44).

Ese problema emocional será tomado en cuenta por los organismos militares de Estados Unidos en las siguientes grandes guerras libradas: las guerras del Golfo y la guerra de Afganistán, donde los militares mostrarán mayoritariamente bombardeos de noche con visión nocturna. Dado que las imágenes eran ya parte de la vida de la gente, y que la gente era una imagen de sí misma, y ya que la tecnología exigía precisión y exactitud, el resultado fue mostrar una imagen emocionalmente soportable de la guerra o proporcional a las mismas imágenes que el "pueblo americano" se había hecho de sí, o mejor, se había hecho mediáticamente. Ser quien quiero ser, antigua máxima de la libertad, es ahora querer ser la imagen que la tecnología me proporciona para poder ser.

Las emociones tienen que estar ahora bajo el control personal gracias a la tecnología, es decir, porque no hay emociones soportables fuera de lo mediático. Así, la misma tecnología que acerca la guerra como imagen, la misma tecnología que se usa en la guerra (y la misma precisión que se exige al cese de esta), es la misma tecnología que se reclama para poner a salvo al sujeto del daño: la tecnología tiene que ofrecer el control de salirse de ese mundo cruel. Dicho de otro modo: de forma germinal, el mismo control demandado tecnológicamente en las guerras y que ha ofrecido un nuevo estilo de vida es el control que el ciudadano pide para su vida. Si ello significa sacrificar la vida real por una vida tecnológica pero que implique un control "ficticiamente" total sobre ella, el ciudadano empezará a estar culturalmente predispuesto a ello. Todo menos ver niñas consumidas por "el fuego".

§5. LO VIRTUAL COMO NUEVO ESCENARIO BÉLICO: CONCLUSIÓN NO CERRADA

La tecnología, en el fondo, es saber cómo proporcionar y dirigir el movimiento de las cosas y darle posibilidad al mundo, genera una potencia y movimiento energético tan capaz de destruir como de dominar. Pero cabe preguntarse si estamos ante un nuevo modo de entender lo tecnológico. Desde 
un punto de vista náutico, la tecnología tiene que ver con cómo lidiar con el movimiento y con dar posibilidad al mundo, y ahora nuestro "fuego" es la batería de nuestros teléfonos u ordenadores.

Nuestras páginas web nos permiten ver lugares y llegar a ellos de una manera que solo con nuestro movimiento fisiológico sería agotador, y no por casualidad, ahora navegamos por la red. Las páginas web, como los puertos virtuales en los que anclar nuestros barcos, se han designado como dominios o portales, es decir, casas o puertos. Nuestras "casas" y domesticaciones son "dominios web", y ahora son nuestras computadoras las que tienen puertos similares a aquellos muelles de la costa fenicia o romana. También, como es el espacio extraterrestre y no el mar el límite de la realidad, ya no surcamos el mar, sino que "subimos a la nube". Y resulta que, teniendo en cuenta todas las diferencias, pero también nuestra forma de hablar al respecto, ahora navegamos con un clic y podemos ver imágenes que solo con nuestro alcance físico serían imposibles.

Es ahora cuando podemos preguntar: ¿cómo se convierte esta tecnología en una parte estructural de nuestras vidas? Además, ¿cuáles son las consecuencias de esta "conformación"?

No está del todo claro que el uso masivo de la tecnología sea lo que diferencia nuestra era de otras, más bien, parece que es el puesto en el que se sitúa de cara a la comprensión del mundo y el modo en el que el individuo se ha entregado a ella para evitar la crueldad del mundo. La tecnología ya no es un medio para ampliar la realidad, para darle posibilidades a esta, o no solo, sino también y mayoritariamente el acceso primario y esencial para vivirla y, sobre todo, contemplarla. La tecnología no ha pasado de medio a fin, de posibilidad a dominio del mundo, sino que se ha vuelto el mundo mismo, el nexo donde se unen "palabra, sonido e imagen" (Sartori, 2002: 36).

El campo tecnológico ha adquirido el incentivo permanente de reemplazar la realidad: es el medio (los medios) intentando ser el filtro cognoscitivo de cualquier fin, es decir, un medio que intenta hacerse más real que la realidad positiva. Así, no es la tecnología sino la realidad la que se ha vuelto mediática. Las nuevas guerras ya no serán por la tecnología sino tecnológicas: son guerras dentro de un nuevo escenario (red) en las que no es la vida fuera de la tecnología (empírica) la que tiene la consistencia de lo real, sino que ahora 
es la vida que permanece ajena y no gobernada por cualquier mediación tecnológica la que se ha convertido en virtual o, peor aún, esa "vida real" tiene que demostrarse tecnológicamente para certificarse como tal. Lo que ahora se ha convertido en algo fantasmal e irrelevante es lo que hemos dejado fuera de la realidad mediática, es decir, lo que se ha vuelto irrelevante es el mundo empírico o más fáctico: vivimos en una realidad virtual para hacernos, paradójicamente, visibles para los demás.

La visibilidad de la imagen en la que vivimos no se concibe a sí misma como una mera copia o retrato de la realidad, sino que estanca y congela la realidad de una manera que lo que no aparece en ella es absolutamente irrelevante. No comentamos sobre la realidad de las cosas empíricas, sino sobre la realidad que hay en la imagen digital que tenemos de ellas, porque ahora son las imágenes tecnológicas y virtuales de lo real las que le dan el mismo estatus de realidad. Lo que está visible en este momento ya no es la realidad frente a nosotros, lo que está visible es "la imagen de la realidad" frente a nuestros dispositivos tecnomediáticos. La precisión que se pedía para los artilugios militares es también un requerimiento para una cámara de un teléfono o la pantalla de un televisor, y nos convertimos en las imágenes de nosotros mismos, es decir, en aquellas imágenes que estamos mostrando en aquellos dispositivos.

Ahora la tecnología ya no es posibilidad del mundo, sino el propio mundo. Y está por ver el control de esos nuevos "puertos", "dominios" y "navegaciones". Las guerras son mediáticas, pero no porque la tecnología es el medio que nos permite controlar el mundo, sino porque los medios son, ahora y por fin, el propio mundo.

La idea de que nos convertimos en imágenes de nosotros mismos es otra forma de decir que el gran dilema que planteaba Platón en su alegoría de la caverna ya no es un dilema metafórico. Más: es que el sujeto entiende que su victoria en el mundo es precisamente poder convertirse en esa imagen: las batallas son batallas de imágenes. Así, no es tanto que por ignorancia se desconoce la diferencia en la imagen y la realidad, sino que conocedor de esa imagen el sujeto quiere vivir en ella o el mundo solo le deja vivir en ella.

Para que esto sea posible el sujeto contemporáneo ha de convertirse en aquello que los televisores de los años sesenta empezaron a mostrar: ser 
espectadores, primero de una guerra que no se quiere ver, para luego vivir en una imagen creada bajo nuestro control. Pero entonces, como dice Marín, "el espectador se queda sin sustancia. La vida y la imagen ajena suplanta a la propia", porque desparecido el sujeto solo le queda la posibilidad de identificarse con el objeto que ve, esto es, "los espectadores están tan solos como poseídos por las mismas e idénticas imágenes" (Marín, 2013: 151).

Si la tecnología era dar posibilidades al mundo, abrirlo, hacerlo dar más de sí, ahora sigue haciendo algo semejante: da posibilidades, pero no a este sino a otro mundo, a un mundo virtual tomado como real, donde, como dice Baumann, "no es cuestión de amar u odiar al prójimo, sino de mantenerlo a distancia" (Baumann, 2017: 66). Esa distancia la abre ese nuevo movimiento. Hace falta olvidarnos de lo real para ir al lugar que la propia tecnología ha creado y abierto para nosotros. Aquel mundo posible, que o bien era el mejor por ser posible o bien era el peor porque era la única posibilidad, se ha vuelto más real que el peor de los mundos reales. La guerra ha de ser ahora, para rechazarla o apoyarla, tan tecnológica como el espectador que la contempla, a saber: espectáculo virtual ${ }^{22}$.

\section{REFERENCIAS BIBLIOGRÁFICAS}

Alvira, R. (1999). Filosofia de la vida cotidiana. Rialp.

Aristóteles (1988). Acerca del alma. Gredos.

Aristóteles (1990). Metafisica. Gredos.

Aristóteles (1995). Física. Gredos.

Aristóteles (2017). Política. Centro de Estudios Políticos y Constitucionales. Baumann, Z. (2017). La globalización. Consecuencias humanas. FCE.

\footnotetext{
${ }^{22}$ Se trata de buscar la correspondencia exacta en la que un espectador, un espectro y un espejo (una imagen) puedan vivir armoniosamente y ese lugar no es otra cosa que un espectáculo. Es significativo que a finales del siglo xx hasta 1960 el que era considerado -y así se bautizó-el mayor espectáculo del mundo, y que fue una novedad cultural en su momento, no fue otro que el circo. Las casas de los espejos, los inventos, los transformismos de todo tipo, el lugar donde los sueños se hacen reales, donde el transhumanismo se hacía visible, donde incluso se invertía un $25 \%$ de ingresos en publicidad: todo es un circo hasta finales de los años cincuenta (Daniel, 2016).
} 
Beevor, A. (2012). La Segunda Guerra Mundial. Weidenfeld y Nicolson.

Bellomo, R. (1993). A methodological approach for identifying archaeological evidence of fire resulting from human activities. Journal of Archaeological Science 20, 525-554.

Bethke, B. (2016). Dog Days To Horse Days: Evaluating The Rise Of Nomadic Pastoralism Among The Blackfoot [tesis doctoral, University of Arizona].

Blumenberg, H. (1947). Beiträge zum Problem der Ursprünglichkeit der mittelalterlich-scholastischen Ontologie. Kiel. [Disertación inédita].

Blumenberg, H. (1951). Das Verhältnis von Natur und Technik als philosophisches Problem. Studium Generale 4(8), 461-467.

Blumenberg, H. (1955). Der kopernikanische Umsturz und die Weltstellung des Menschen. Eine Studie zum Zusammenhang von Naturwissenschaft und Geistesgeschichte. Studium Generale 8(10), 637-648.

Blumenberg, H. (1963). Lebenswelt und Technisierung unter Aspekten der Phänomenologie. Filosofia 14, 855-884.

Blumenberg, H. (1964). Wirklichkeitsbegriff und Möglichkeit des Romans. En Hans Robert Jauss (Ed.), Nachahmung und Illusion (Poetik und Hermeneutik, I) (pp. 9-27). Fink.

Blumenberg, H. (1971). Approccio antropologico all'Attualitá della Retorica. Il Verri. Rivista di Letteratura 35/36, 49-72.

Blumenberg, H. (1981). Wirklichkeiten in denen wir leben. Aufsätze und eine Rede. Reclam.

Brown, C. (1999). Lexical Acculturation Native American Languages. Oxford University Press.

Campillo J. E. (2007). La cadera de Eva. El protagonismo de la mujer en la evolución humana. Crítica.

Comellas, J. L. (2000). El último cambio de siglo. Ariel.

Choza, J. (1998). Ulises. Un arquetipo de la existencia humana. Ariel.

Choza, J. (2013). “Artes marciales. La guerra y la identidad colectiva”. Thémata. Revista de Filosofía 48, 25-35. 
Cronin, B. (2013). "Reckless endangerment warfare: Civilian casualties and the collateral damage exception in international humanitarian law". Journal of Peace Research 50(2), 175-187.

Dinael, N. (2016). The Circus 1870-1950. Taschen.

Francis, R. (2015). Domesticated: Evolution in a Man-Made World. Norton.

Fuentes, A. (2017). La chispa creativa. Cómo la imaginación nos hizo inteligentes. Ariel.

Geertz, C. (1973). The Interpretation of Cultures: Selected Essays. Basic Books.

Goldberg, P. et al. (2010). New evidence on Neandertal use of fire: Examples from Roc de Marsal and Pech de l'Azé IV. Quaternary International 207.

Heidegger, M. (1958). La pregunta por la técnica. Revista de Filosofia 1. Versión original, M. Heidegger (1967). Die Frage nach der Technik. En Vorträge and Aufsätze (vol. I, pp. 5-36). Neske.

Heidegger, M. (1992). Platon: Sophistes (WS 1924/1925), GA 19, Klostermann.

Heidegger, M. (1995). Der Ursprung des Kunstwerkes. Holzwege, GA 5, Klostermann.

Heidegger, M. (1996). ¿Y para qué poetas? Caminos de bosque. Alianza Editorial.

Hariman, R. y Lacaites, J. L. (2007). No Caption Needed: Iconic Photographs, Public Culture, and Liberal Democracy. University of Chicago Press.

Hernández-Pacheco, J. (2008). El duelo de Atenea. Reflexiones sobre guerra, milicia y humanismo. Encuentro.

Homero. (1993). La Odisea. Gredos.

Keegan J. (2014). Historia de la Guerra. Truner.

Larson, G., Fuller, D. Q. (2014). Evolution of Animal Domestication. Annual Review of Ecology Evolution and Systematics 66, 115-136.

Latour, B. (1992). Ciencia en Acción. Barcelona: Labor.

Marín, H. (2010). Teoría de la cordura. Y de los hábitos del corazón. Pre-Textos. 
Marín, H. (2013). El hombre y sus alrededores. Cristiandad.

Marín, H. (2019). Mundus. Nuevo Inicio.

Morris, W. (2016). La era del sucedáneo y otros textos contra la civilización moderna. Pepita de Calabaza.

Ortega y Gasset, J. (1983). Meditación de la técnica. Obras completas, tomo $V$. (pp. 317-375). Alianza.

Platón. (1993). Protágoras. Diálogos I. Gredos.

Polo, L. (1991). Quién es el hombre. Rialp.

Ponte, V. (2007). Régimen jurídico de las vías públicas en el derecho romano. Dykinson.

Price, N. (2020). Vikingos. La historia definitiva de los pueblos del norte. Ático de los libros.

Pyne, S. (1997). World Fire. The culture of Fire on Earth. University of Washington Press.

Roebroeks, W., Villa, P. (2011). On the earliest evidence for habitual use of fire in Europe. Proceedings of the National Academy of Science of the United States of America 108, 5209-5217.

Rosas, A. (2010). Los Neandertales. CSIC.

Rosas, A. (2015). Los primeros homínidos. CSIC.

Ruetz, J., LaDuke, Th. (2010). Reaction to fire by savanna chimpanzees (Pan troglodytes verus) at Fongoli, Senegal: Conceptualization of 'fire behavior' and the case for a chimpanzee model. American Journal of Physical Anthropology 141(4), 646-50.

Sandgathe, Dennis M., Dibble, Harold L. et al. (2011). Timing of the appearance of habitual fire use. Proceedings of the National Academy of Science of the United States of America 108, 29 y ss.

Sartori, G. (2002). Homo videns. La sociedad teledirigida. Taurus.

Serrano de Haro, A. (2007). La precisión del cuerpo. Trotta.

Shaw, I. (2007). Historia Oxford del Antiguo Egipto. La esfera de los libros.

Spaemann, R. (1989). Lo natural y lo racional. Rialp.

Tattersall, I. (2012). Los señores de la tierra. Pasado y Presente. 
Turbón, D. (2006). La evolución humana. Ariel.

Valderrama, J.C. (2017). “Agón” y "Polémos". Polemocentrismo analítico y prioridad práctica de la amistad en el pensamiento político de Julien Freund. Contrastes XXII(1), 119-136.

Walaker, S. (2011). Death in Abundance - quickly! The Oseberg Ship Burial in Norway. Acta Archaeologica 82, 7-15.

Wrangham, R. (2009). Catching Fire: How Cooking Made Us Human. Basica Books.

Wrangham, R. (2019). The Goodness Paradox: The Strange Relationship between Virtue and Violence in Human Evolution. Pantheon. 